\title{
Peningkatan Hasil Belajar Bahasa Jawa Materi Menulis Karangan Cerita Peristiwa Alam dengan Media Power Point pada Siswa Kelas V SD
}

\section{Purwati}

SDN Sugiharjo 02 Pati

purwati19650205@gmail.com

\section{Sejarah Artikel \\ diterima 03/09/2018}

disetujui 25/08/19

\begin{abstract}
The research is based on the students difficulties in writing stories. The research aims to determine if the Power Point media can improve the learning outcomes of grade $V$ students on Javanese language subjects. This research is classroom action research with qualitative and quantitative descriptive approaches. The research uses two cycles. Each cycle consists of planning, implementation, observation and reflection phases. The data collection techniques use observation, tests and documentation. The research subjects are 19 students of fifth grade at SDN Sugiharjo 02 Pati. In the first cycle, the learning mastery is $63.16 \%$ or two students fail with score 74.21 . In the second cycle, $100 \%$ of students pass the learning mastery with an average score 78.68. It concludes that Power Point can improve the learning outcomes of fifth grade students of SDN Sugiharjo 02 Pati in the subject of Javanese language especially in writing essay about natural phenomenon in the second semester of academic year 2017/2018.

Keywords: writing essay, Power Point, learning outcomes, Javanese language
\end{abstract}

\begin{abstract}
Abstrak
Penelitian ini didasarkan pada kesulitan siswa menuliskan cerita. Penelitian ini bertujuan untuk mengetahui apakah media Power Point dapat meningkatkan hasil belajar siswa kelas $\mathrm{V}$ pada mata pelajaran bahasa Jawa menulis cerita. Jenis penelitian tindakan kelas dengan pendekatan deskriptif kualitatif dan kuantitatif.Penelitian ini menggunakan dua siklus, setiap siklus terdiri dari tahap perencanaan, implementasi, observasi dan refleksi.Teknik pengumpulan data penelitian ini menggunakan teknik observasi, tes dan dokumentasi. subjek penelitian adalah 19 siswa kelas V SDN Sugiharjo 02 Pati. Pada siklus I ketuntasan hasil belajar siswa sebesar $63,16 \%$ atau 2 tidak tuntas dengan nilai 74,21 . Pada siklus II $100 \%$ siswa tuntas dengan nilai rata-rata 78,68. Kesimpulan penelitian ini Power Point dapat meningkatkan hasil belajar siswa kelas $\mathrm{V}$ SDN Sugiharjo 02 Pati pada mata pelajaran bahasa jawa materi menulis karangan cerita tentang peristiwa alam semester 2 tahun pelajaran 2017/2018.

Kata Kunci: menulis karangan, power point,hasil belajar, bahasa jawa
\end{abstract}




\section{PENDAHULUAN}

Pendidikan adalah salah satu komponen dalam memajukan bangsa, dimana semakin maju pendidikan pada suatu bangsa, maka turut maju pula bangsa tersebut. Hal ini terlihat dari negara-negara tetangga yang dimana pendidikan sangat diperhatikan kemajuannya menjadai faktor negara tersebut menjadi negara maju. Di Indonesia sampai saat ini masih menjadi negara berkembang yang dikarenakan masih berubahubahnya kurikulum yang digunakan.

Pendidikan dapat dikatakan sebagai kunci keberhasilan suatu bangsa. Melalui pendidikan suatu bangsa dapat menjadi mandiri, kuat, dan berdaya saing tinggi dengan cara membentuk generasi muda yang bertaqwa kepada Tuhan Yang Maha Esa, berkarakter, cerdas, dan memiliki keterampilan. Hal ini ssuai dengan Undang-undang Nomor 20 Tahun 2003 tentang Sistem Pendidikan Nasional Pasal 1 ayat 1 yang berisi : "Pendidikan adalah usaha sadar dan terencana untuk mewujudkan suasana belajar dan proses pembelajaran agar peserta didik secara aktif mengembankan potensi dirinya untuk memiliki kekuatan spiritual keagamaan, pengendalian diri, kepribadian, keceerdasan, akhlak mulia, serta ketrampilan yang diperlukan dirinya, masyarakat, bangsa, dan negara".

Pendidikan bahasa daerah jawa atau Bahasa Jawa menjadi salah satu masalah oleh SD Negeri Sugiharjo 02. Hal ini diketahui melalui hasil Ulangan siswa kelas $V$ SD Negeri Sugiharjo 02 Pati pada mata pelajaran Bahasa Jawa materi menulis karangan yang menyebutkan bahwa dari 19 siswa6 anak mendapat nilai 60,5 anak mendapat nilai 65,4 anak mendapat nilai 70, 2 anak mendapat nilai 75, 2 anak mendapat nilai 80 dengan Kriteria Ketuntasan Minimal (KKM) 70. Dari data tersebut nilai rata-rata siswa kelas $\mathrm{V}$ dalam menulis karangan mata pelajaran Bahasa Jawa sebesar 67,11. Berdasarkan data tersebut dapat diketahui bahwa hanya 8 anak yang memenuhi KKM dan sebanyak 11 anak tidak memenuhi KKM. Hal ini dapat dikatakan bahwa hasil belajar siswa kelas V SD Negeri Sugiharjo 02 Pati pada mata pelajaran Bahasa Jawa materi Menulis Karangan masih rendah.

Menulis adalah salah satu ketrampilan berbahasa. Menulis memiliki beberapa jenis yaitu diskripsi, narasi, eksposisi, persusi dan argumentasi. Masing-masing dari jenis tersebut memiliki tujuan sendirisendiri. Menulis sangat erat kaitannya dengan mengarang, guru maupun orang tua harus mengajarkan anak mengarang sejak dini karena akan mempengaruhi tumbuh kembang anak dalam ranah kognitif dan psikomotor. Guru dalam sekolah harus mengajarkan pengajaran mengarang agar siswanya terbiasa berpikir kreatif dan hal itu penting dilakukan dalam pembelajaran. Suroso (2009:41) mengemukan pengajaran mengarang diarahkan untuk mencapai beberapa tujuan. Tujuan pertama, agar para siswa bisa menggunakan karangan untuk memenuhi beberapa keperluan. Tujuan kedua, agar siswa bisa melakukan kegiatan dalam proses penulisan. Tujuan ketiga, agar siswa menguasai bentuk bahasa tulis yang meliputi konvensi bahasa penggunaan bahasa dan mekanik. Tujuan keempat, agar siswa memahami 
peran bahasa tulis dalam komunikasi antar perorangan, merekam kehidupan masyarakat serta meningkatkan diri menulis.

Hasil belajar menurut Dimyati dan Mudjiono (2009:3) merupakan hasil dari suatu interaksi tindak belajar dan mengajar. Anunurrahman (2009:37-38) menyatakan hasil belajar ditandai dengan perubahan tingkah laku. Sedangkan menurut Bloom (Suprijono, 2016:6-7) hasil belajar mencakup keemampuan kognitif, afektif, dan psikomotorik. Berdasarkan beberapa definisi tersebut, maka dapat disimpulkan bahwa hasil belajar adalah suatu perubahan tingkah laku yang diperoleh melalui suatu tindakan belajar dimana perubahan ini berkenaan dengan aspek kognitif, afektif, dan psikomotorik.

Seorang guru yang baik adalah guru yang mampu memperbaiki serta meningkatkan hasil belajar peserta didiknya. Siswa sulit menulis karangan bahasa jawa karena siswa kurang menguasai ragam kata dalam bahasa jawa, ragam kata ini disebabkan oleh lingkungan keluarga maupun masyarakat yang kurang menggunakan ragam kata bahasa jawa. Seperti penelitian dari Suryadi (2014) yang berjudul "Penggunaan Tingkat Tutur Bahasa Jawa Ngoko Dan Krama Pada Ranah Keluarga dan Masyarakat Di Kota Semarang dan Kota Pekalongan" dalam penelitian ini dijelaskan bahwa di daerah Semarang dan Pekalongan sudah mengalami pergeseran penggunaan ragam kata bahasa jawa dan mulai tergantikan oleh bahasa Indonesia, hal inilah yang menyebabkan penguasaan kata bahasa jawa siswa kurang. Oleh karena itu, perlu dilakukan perbaikan terhadap hasil belajar bahasa jawa materi menulis karangan siswa kelas
$\mathrm{V}$ tersebut melalui Penelitian Tindakan Kelas (PTK). Upaya tindakan perbaikan dimaksudkan sebagai pencarian jawaban atas permasalahan yang dialamai guru dalam melaksanakan pembelajaran sehari-hari. Pemberian tindakan dapat berupa metode, model, media pembelajaran, bahan ajar, atau alat peraga. Pemilihan tindakan harus dipikirkan secara matang dan sebisa mungkin harus dapat memperbaiki masalah hasil belajar siswa.

Rendahnya hasil belajar bahasa jawa materi menulis karangan pada siswa kelas V SD Negeri Sugiharjo 02 Pati dipengaruhi oleh beberapa faktor, diantaranya : (1) Guru sebagai peneliti belum menggunakan media pembelajaran yang menarik bagi peserta didik, (2) Peserta didik merasa kesultan dalam memahami materi yang disampaikan oleh guru, dan (3) Peserta didik belum dapat menguasai tehnik menulis karangan yang benar.

Berdasarkan permasalahan di atas, solusi yang dapat diberikan adalah sebuah tindakan dengan menggunakan media pembelajaran Power Point (PPT) pada materi Menulis Karangan Mata Pelajaran Bahasa Jawa kelas V SD Negeri Sugiharjo 02 Pati. Berdasarkan solusi tersebut, maka judul dari Penelitian Tindakan Kelas ini adalah "Peningkatan Hasil Belajar Bahasa Jawa Materi Menulis Karangan cerita peristiwa alam dengan Media Power Point pada Siswa Kelas V SDN Sugiharjo 02 Pati".

Media pembelajaran Power Point adalah salah satu produk microsoft cooperation yang paling banyak digunakan sebagai media bantu dalam menyampaikan informasi seperti dalam proses pembelajaran. Menurut Istiningsih (2012:119) 
manfaat microsoft power pont dalam pembelajaran antara lain : Penyampaian materi pembelajaran lebih menarik, menciptakan pembelajaran yang efektif dan efisien dan materi pembelajaran disampaikan secara utuh melalui pointer-pointer materi. Media berbasis power point memiliki kemampuan pengolahan teks, warna, gambar, serta animasianimasi yang bisa diolah sendiri sesuai kreativitas pengguna. Selain itu, media berbasis power point dapat untuk menambah gambar, video, audio, dan memungkinkan untuk membuat soal interaktif. Dalam penelitian ini power point digunakan guru untuk lebih mudah mengajarkan dan menampilkan materi: cara membuat karangan dan ragam bahasa jawa yang akan menambah penguasaan kosakata bahasa jawa siswa. Keunggulan lain adalah media ini penggunaannya mudah, pengoprasian simpel dan siswa bisa melihat dengan jelas apa yang akan disampaika guru.

Media power point dapat membuat pembelajaran menarik dan miningkatkan hasil belajar, hal ini diperkuat dengan penelitian Srimaya (2017) yang berjudul "Efektivitas Media Pembelajaran Power Point untuk Meningkatkan Motivasi dan Hasil Belajar Biologi Siswa". Motivasi siswa pada siklus 1 diperoleh hasil rata-rata sebesar 63,31 dan meningkat menjadi 79,81 pada siklus 2. Selain itu hasil belajar siswa juga mengalami peningkatan pada siklus 1 ke siklus 2. Pada siklus 1 diperoleh hasil rata-rata sebesar 47,52 meningkat menjadi 79,92.

Penelitian dari Permatasari
(2015) berjudul "Pengaruh Penggunaan Multimedia Powerpoint terhadap Peningkatan Kemampuan
Menulis Cerita Pendek pada Pembelajaran Bahasa Indonesia (Quasi Eksperimen di Kelas 7 Smpn I Tarogong Kaler Tahun 2014-2015)" diperoleh nilai rata-rata pretes adalah 63,19 dan tidak memenuhi standar Kriteria Ketuntasan Minimal (KKM) yaitu 68. Pada nilai postes mengalami peningkatan menjadi 77,14 dan memenuhi standar KKM. Rata-rata Gain berada pada interval $0,30 \mathrm{~s} / \mathrm{d}$ 0,70 yang berarti bahwa peningkatan kemampuan belajar setelah menggunakan multimedia PowerPoint termasuk ke dalam kategori sedang.

Kartika, Erna (2015) yang berjudul "Penggunaan Media Power Point Untuk Meningkatkan Hasil Belajar Mata Pelajaran IPS Siswa di Kelas VI SDN Kaliasan VII Surabaya". Dalam penelitian tindakan kelas tersebut terbukti media Power Point 'dapat meningkatkan hasil belajar yang ditandai pada prasiklus hasil siswa yang memilikinilai di bawah KKM ada 9 dari 28 siswa dengan presentase sekitar 32\%. Setelah dilakukan penelitian menggunakan media power point pada siklus I memperoleh $64 \%$ dan pada siklus II meningkat menjadi $86 \%$. Jadi dapat disimpulkan bahwa media power point dapat meningkatkan hasil belajar siswa. Penelitian yang dilakukan peneliti berbeda dengan penelitian tersebut karena bahasa jawa adalah mata pelajaran yang berbeda dengan mata pelajaran IPS. Penelitian ini bukan hanya menampilkan materi lewat power point. Namun juga, kosa kata bahasa jawa yang dapat digunakan siswa untuk membuat karangan. selain mata pelajaran dan sekolah yang berbeda, penggunaan media ini didasari dengan fasilitas yang ada di sekolah yang digunakan dalam setting penelitian. 


\section{METODE}

Jenis penelitian yang digunakan adalah penelitian tindakan kelas (PTK). Menurut Kasihani (Sukayati, 2008:8) Penelitian Tindakan Kelas (PTK) adalah penelitian praktis yang bertujuan untuk memperbaiki kekurangankekurangan dalam pembelajaran di kelas dengan cara melakukan tindakan-tindakan. Teknik pengambilan data menggunakan teknik observasi, tes dan dokumentasi. Nasution (2003:127) mengemukakan "observasi adalah dasar semua ilmu pengetahuan. Para ilmuan hanya dapat bekerja berdasarkan data, yaitu fakta mengenai dunia kenyataan yang diperoleh melalui observasi". Dokumentasi digunakan sebagai alat bukti dalam penelitian.

Pada penelitian ini, peneliti menyajikan data berupa deskriptif data kualitatif hasil penelitian berupa angka-angka hasil tes. Tahap penyimpulan data pada tahap ini, peneliti menarik kesimpulan dari gambaran data yang diperoleh. Dengan demikian kesimpulan dalam penelitian kualitatif dapat menjawab rumusan masalah atau merupakan temuan baru yang sebelumnya belum ada. Dalam kegiatan analisis data tersebut akan didapatkan dua jenis data yaitu data kualitatif dan data kuantitatif. Data kualitatif berupa deskripsi data dari hasil angka-angka yang diperoleh melalui tes dan data kuantitatif ialah angka-angka hasil tes siswa tersebut.

Tempat peneliti mengadakan penelitian Tindakan Kelas adalah di SDN Sugiharjo 02 Kecamatan Pati Kabupaten Pati. Subyek penelitian TIndakan Kelas adalah siswa kelas V SDN Sugiharjo 02 kecamatan Pati
Kabupaten Pati semester 2 tahun pelajaran 2017/2018. Jumlah siswa kelas $\mathrm{V}$ adalah 19 dengan perincian 9 siswa laki-laki dan 10 siswa perempuan Penelitian Tindakan Kelas (PTK) ini terdiri dari 2 siklus. Langkahlangkah tiap siklus terdiri dari : Perencanaan, tindakan, pengamatan, refleksi. Langkah-langkah tiap siklus terdiri dari : Perencanaan, tindakan, pengamatan, refleksi.

Pada Siklus 1

Tahap perencanaan

Peneliti menyiapkan RPP, di dalam RPP terdapat Kegiatan apersespsi, kegiatan inti, penutup, menyiapkan lembar kerja, menyiapkan lembar observasi, menyiapkan soal tes, kisi-kisi, kunci jawaban, penskoran, soal remedial, soal pengayaan.

Tahap Tindakan

Peneliti

melaksanakan

pembelajaran di kelas $\mathrm{V}$, dimulai dari apersepsi, kegiatan inti, memberi lembar kerja,menggunakan media pembelajaran TIK Power point namun tidak direfleksi, melaksanakan tes akhir pelajaran menganalisis, member perbaikan bagi siswa yang nilainya belum tuntas, dan memberi pengayaan bagi siswa yang telah tuntas.

Tahap Pengamatan

Peneliti mengajak teman sejawat untuk mengamati proses belajar mengajar yang dilakukan oleh peneliti, Observer mencatat semua prosese pembelajaran di kelas $\mathrm{V}$.

Tahap refleksi

Peneliti bersama dengan pembelajaran yang telah dilakukan oleh peneliti, Observer memberikan masukan dan kritikan sesuai dengan pengamatan observer, menentukan 
langkah selanjutnya yaitu melaksanakan siklus 2 .

Siklus 2

Tahap perencanaan

Peneliti menyiapkan RPP, di

dalam RPP terdapat Kegiatan apersepsi, kegiatan inti, penutup, menyiapkan lembar kerja, menyiapkan lembar observasi, menyiapkan soal tes, kisi-kisi, kunci jawaban, penskoran, soal remedial, soal pengayaan.

Tahap Tindakan

Peneliti

melaksanakan

pembelajaran di kelas $\mathrm{V}$ dimulai dari apersepsi, kegiatan inti, memberi lembar kerja,menggunakan media pembelajaran TIK Power point dengan direfleksi, melaksanakan tes akhir pelajaran menganalisis, memberi perbaikan bagi siswa yang nilainya belum tuntas, dan memberi pengayaan bagi siswa yang telah tuntas.

Tahap Pengamatan

Peneliti mengajak teman sejawat untuk mengamati proses belajar mengajar yang dilakukan oleh peneliti, Observer mencatat semua proses pembelajaran di kelas $\mathrm{V}$.

Tahap refleksi

Peneliti bersama dengan observer membahas tentang pembelajaran yang telah dilakukan oleh peneliti, Observer memberikan masukan dan kritikan sesuai dengan pengamatan

\section{PEMBAHASAN}

Deskripsi Data hasil belajar siswa dalam menulis karangan cerita tentang peristiwa alam pada mata pelajaran bahasa Jawa bagi siswa kelas V SDN Sugiharjo 02 semester 2 tahun pelajaran 2017/2018 pada prasiklus. Dari 19 siswa dalam menulis karangan mata pelajaran Bahasa Jawa terdapat 6 siswa yang mendapat nilai 60,5 siswa mendapat nilai 65,4 siswa mendapat nilai 70,2 siswa mendapat nilai 75,2 siswa mendapat nilai 80. Dari data tersebut nilai rata-rata siswa kelas $\mathrm{V}$ dalam menulis karangan cerita tentang peristiwa alam mata pelajaran Bahasa Jawa 67,11 . Jadi siswa yang tuntas $47,37 \%$ dan yang tidak tuntas $52,63 \%$.

\section{Tabel 1. Data Nilai Hasil Belajar Prasiklus}

\begin{tabular}{ccc}
\hline No & Nilai & $\begin{array}{c}\text { Banyak } \\
\text { Siswa }\end{array}$ \\
\hline 1 & 60 & 6 \\
2 & 65 & 5 \\
3 & 70 & 4 \\
4 & 75 & 2 \\
5 & 80 & 2 \\
\hline
\end{tabular}

Deskripsi Data hasil belajar siswa dalam menulis karangan cerita tentang peristiwa alam pada mata pelajaran bahasa Jawa bagi siswa kelas SDN Sugiharjo 02 semester 2 tahun pelajaran 2017/2018 pada siklus I. Dari 19 siswa dalam menulis karangan mata pelajaran Bahasa Jawa terdapat 2 siswa yang mendapat nilai 65,5 siswa mendapat nilai 70,8 siswa mendapat nilai 75,2 siswa mendapat nilai 80,2 siswa mendapat 
nilai 85. Dari data tersebut nilai ratarata siswa kelas $\mathrm{V}$ dalam menulis karangan cerita tentang peristiwa alam mata pelajaran Bahasa Jawa 74,21 . Jadi siswa yang tuntas $63,16 \%$ dan yang tidak tuntas $36,84 \%$. Berdasarkan uraian di atas, kendala yang dimiliki siswa adalah kebingungan dalam menentukan ide karangan dan saat merangkai kata, siswa yang bingung tampak gelisah dan tak jarang bertanya kepada temannya. Hal ini berakibat fatal karena temannya merasa terganggu. Selain itu, ada beberapa siswa yang tampak kurang percaya diri saat menulis karangan. Hal itu dapat dilihat saat guru berkeliling mencoba melihat hasil pekerjaan siswa

Tabel 2. Data Nilai Hasil Belajar Menulis Karangan Siklus I

\begin{tabular}{ccc}
\hline No & Nilai & $\begin{array}{c}\text { Banyak } \\
\text { Siswa }\end{array}$ \\
\hline 1 & 65 & 2 \\
2 & 70 & 5 \\
3 & 75 & 8 \\
4 & 80 & 2 \\
5 & 85 & 2 \\
\hline
\end{tabular}

Deskripsi Data hasil belajar siswa dalam menulis karangan cerita tentang peristiwa alam pada mata pelajaran bahasa Jawa bagi siswa kelas V SDN Sugiharjo 02 semester 2 tahun pelajaran 2017/2018 pada siklus II.Dari 19 siswa dalam menulis karangan mata pelajaran Bahasa Jawa terdapat 9 siswa mendapat nilai 75, 6 siswa mendapat nilai 80, 4 siswa mendapat nilai 85. Dari data tersebut nilai rata-rata siswa kelas $\mathrm{V}$ dalam menulis karangan cerita tentang peristiwa alam mata pelajaran Bahasa Jawa 78,68. Jadi siswa yang tuntas $0,00 \%$ dan yang tuntas $100 \%$. Berdasarkan permasalahan pada siklus pertama, pada siklus kedua ini siswa tampak santai dan tenang saat mengerjakan karena dari siklus pertama, guru mencoba menggunakan media power point untuk memberi materi. Siswa lebih tanggap karena materi disajikan secara visual dan siswa dapat mengevaluasi kesalahannya pada siklus pertama dan mendapatkan solusi sendiri bagaimana cara dia memperbaiki kesalahan tersebut. Karangan yang tampak berantakan pada siklus 1 menjadi lebih rapi dan baik pada siklus 2 . Siswa menjadi percaya diri dan fokus pada karangannya masing-masing.

Tabel 3. Data Nilai Hasil Belajar Menulis Karangan Siklus II

\begin{tabular}{ccc}
\hline No & Nilai & $\begin{array}{c}\text { Banyak } \\
\text { Siswa }\end{array}$ \\
\hline 1 & 75 & 9 \\
2 & 80 & 6 \\
3 & 85 & 4 \\
\hline
\end{tabular}




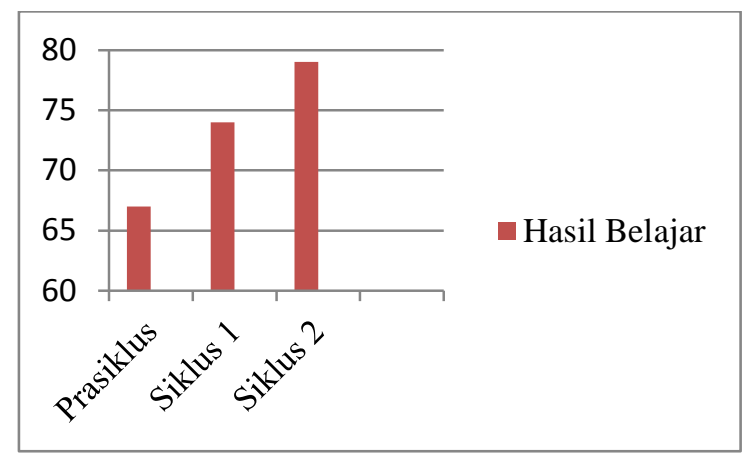

\section{Gambar 1. Diagram Prasiklus, Siklus I dan Siklus II}

Gambar diagram di atas menunjukkan bahwa hasil belajar siswa dalam menulis karangan bahasa jawa mengalami peningkatan dalam setiap siklusnya. Seperti pada uraian data diatas dimana pada prasiklus hanya $47,37 \%$ siswa saja yang lulus dan yang tidak lulus mencapai $52,63 \%$ dengan kriteria 6 siswa mendapat nilai 60,5 siswa mendapat nilai 65,4 siswa mendapat nilai 70,2 siswa mendapat nilai 75 dan 2 siswa mendapat nilai 80.Dari data tersebut nilai rata-rata siswa kelas $\mathrm{V}$ dalam menulis karangan mata pelajaran Bahasa Jawa 67,11. Pada siklus I presentase ketuntasan mengalami peningkatan menjadi $63,16 \%$ dan yang tidak tuntas $37,84 \%$ dengan kriteria2 siswa yang mendapat nilai 65,5 siswa mendapat nilai 70,8 siswa mendapat nilai 75,2 siswa mendapat nilai 80, 2 siswa mendapat nilai 85. Dari data tersebut nilai ratarata siswa kelas $\mathrm{V}$ dalam menulis karangan cerita tentang peristiwa alam mata pelajaran Bahasa Jawa 74,21. Pada siklus II presentase ketuntasan mengalami peningkatan lagi menjadi $100 \%$ yang berarti semua siswa tuntas dengan kriteria 9 siswa mendapat nilai 75,6 siswa mendapat nilai 80 , 4 siswa mendapat nilai 85. Dari data tersebut nilai rata-rata siswa kelas $\mathrm{V}$ dalam menulis karangan cerita tentang peristiwa alam mata pelajaran Bahasa Jawa 78,68. Selain pada nilai, kepercayaan diri siswa juga mengalami peningkatan, kosa kata yang digunakan lebih rapi pada siklus 2 daripada siklu-siklus sebelumnya. Hal ini tampak pada prasiklus yang dimana siswa masih bingung dengan ide dan cara menulis karangan kemudian pada siklus 1 siswa masih kebingungan cara menulis karangan dan menggunakan kosa kata. Di siklus 2 seakan kesalahan yang terjadi pada prasiklus dan siklus 1 sudah teratasi.

\section{SIMPULAN}

Dari data di atas diketahui bahwa pada prasiklus rata-rata hasil belajar mata pelajaran Bahasa Jawa materi menulis karangan cerita tentang peristiwa alam pada siswa kelas V SDN Sugiharjo 02 Pati semester 2 tahun pelajaran 2017/2018 adalah 67,11 dengan presentase ketuntasan hanya $47,37 \%$, pada siklus
1 peneliti menggunakan media pembelajaran TIK Power Point tanpa refleksi rata-rata hasil belajar mata pelajaran Bahasa Jawa materi menulis karangan pada siswa kelas V SDN Sugiharjo 02 Pati semester 2 tahun 2017/2018 mengalami peningkatan yaitu 74,21 dengan prsentase ketuntasan sebesar $63,16 \%$, pada 
siklus 2 penulis menggunakan media pembelajaran TIK Power Point dengan refleksi ternyata hasil belajar pada mata pelajaran Bahasa Jawa materi menulis karangan pada siswa kelas $\mathrm{V}$ SDN Sugiharjo 02 semester 2 tahun 2017/2018 mengalami peningkatan rata-rata menjadi 78,68 dengan presentase ketuntasan $100 \%$, dengan demikian penggunaan media pembelajaran TIK Power Point dapat meningkatkan hasil belajar pelajaran Bahasa Jawa materi menulis karangan pada siswa kelas $\mathrm{V}$ SDN Sugiharjo 02 semester 2 tahun pelajaran 2016/2017 yaitu mengalami peningkatan dari prasiklus ke siklus I sebesar $15,79 \%$ dan siklus I ke siklus II meningkat sebesar $36,84 \%$. Selain itu media ini dapat meningkatkan pemahaman siswa tentang cara menulis karangan, menentukan ide, menyusun karangan, penguasaan kosa kata dan kepercayaan diri siswa. Jadi pembelajaran menggunakan media power point (PPT) mampu meningkatkan hasil belajar siswa kelas $\mathrm{V}$ mata pelajaran bahasa jawa materi menulis karangan cerita tentang peristiwa alam di SDN Sugiharjo 02 Pati semester 2 tahun pelajaran

\section{SARAN}

Berdasarkan

penelitian tindakan kelas yang dilakukan peneliti di kelas V SDN Sugiharjo 02 Pati semester 2 tahun pelajaran 2017/2018, maka saran yang dapat diberikan kepada guru-guru agar lebih kreatif lagi dalam memanfaatkan teknologi seperti microsoft power point (PPT) untuk membantu penyampaian materi ajar agar siswa cepat paham dengan materi yang diberikan. Dengan memanfaatkan teknologi dalam mengajar menjadi salah satu cara guru untuk mengikuti perkembangan jaman dimana semakin lama teknlogi semakin maju. Jangan sampai guru kalah dengan siswanya dalam memanfaatkan teknologi. Dalam penelitian ini peneliti memiliki keterbatasan dalam menggunakan sarana prasarana yang seadanya, menjadikan power point sebagai mendia mengajar memang menjadi solusi yang bagus. Namun, alangkah baiknya apabila bapak dan ibu guru lebih dapat mengembangkannya menjadi media yang lebih menarik lagi.

\section{DAFTAR PUSTAKA}

Aunurrahman.2012. Belajar dan Pembelajaran. Bandung: Alfabeta.

Dimyati, \& Mudjiono.2009. Belajar dan Pembelajaran. Jakarta: Rineka Cipta.

Istiningsih.2012. Pemanfaatan TIK dalam Pembelajaran. Yogyakarta: Skripta Media Creative.

Kartika, Erna.2015. Penggunaan Media Power Point Untuk
Meningkatkan Hasil Belajar Mata Pelajaran IPS Siswa di Kelas VI SDN Kaliasan VII Surabaya. http://ejurnal.com/2016/2017/pengguna an-media-power-pointuntuk.html?m=1\#more. Diakses pada 22 Juli 2018.

Nasution. 2003. Metode Research. Jakarta: PT. Bumi Aksara.

Permatasari, Anne Anita (2015). Pengaruh Penggunaan 
Multimedia Powerpoint terhadap Peningkatan Kemampuan Menulis Cerita Pendek pada Pembelajaran Bahasa Indonesia (Quasi Eksperimen di Kelas 7 Smpn I Tarogong Kaler Tahun 2014-2015).

http://ejournal.upi.edu/index.php/ pedagogia/article/download/3297 /2283. Diakses pada 15 Maret 2018

Srimaya. (2017). Efektivitas Media Pembelajaran Power Point untuk Meningkatkan Motivasi dan Hasil Belajar Biologi Siswa. http://jurnal.untirta.ac.id/index.ph $\mathrm{p} /$ Candrasangkala/article/downlo ad/2886/2253. Diakses pada 16 Maret 2018

Sukayati. 2008. Penelitian Tindakan Kelas. Yogyakarta: PPPPTK Matematika.
Suprijono.2016. Cooperative Learning Teori \& Aplikasi Paikem. Yogyakarta: Pustaka Pelajar.

Suroso. 2009. Penilaian Tindakan Kelas: Peningkatan Kemampuan Menulis Melalui Classroom Action Research. Yogyakarta: Pararaton.

Suryadi.2014.Penggunaan Tingkat Tutur Bahasa Jawa Ngoko Dan Krama Pada Ranah Keluarga dan Masyarakat Di Kota Semarang dan Kota Pekalongan. https://digilib.uns.ac.id/dokumen/ detail/45295/PenggunaanTingkat-Tutur-Bahasa-JawaNgoko-dan-Krama-pada-RanahKeluarga-dan-Masyarakat-diKota-Semarang-dan-KotaPekalongan. Diakses pada 16 Maret 2018. 